\title{
HKI DAN UU PEMAJUAN KEBUDAYAAN
}

\author{
Agus Sardjono \\ Universitas Indonesia
}

Contact: agus.sardjono@gmail.com

Diterima: 2 juli 2019

Direvisi: 3 Juli 2019

Disetujui: 5 Agustus 2019

Hak Cipta: (C) 2019

Halaman: 45-61

\begin{abstract}
The Constitution 1945 has obligated government to advance culture. Symphonizing Intellectual Property in the advancement of culture must be a major project burdened by government to realize it. The concept of Intellectual Property Rights has been aimed to giving rewards to creative people who maintain momentum by cultural promotion act 2017 enactment. As aconsequence, goverment and society are encourage to be united to execute the law in order to realize the cultural advance in Indonesian in regard to the concept of Intellectual Property Rights. It is becoming the main idea of this writing. Furthermore, this writing is provided accordance with normative legal research method which thr research focused on law as a rule.
\end{abstract}

Keywords: Symphonizing IP, Cultural Promotion, Cultural Advance

\section{PENDAHULUAN}

Belum lama ini Pemerintah Indonesia memberlakukan Undang-undang tentang Pemajuan Kebudayaan (UU 5/17 tentang Pemajuan Kebudayaan). Undang-undang ini merupakan perwujudan dari amanat Konstitusi Republik Indonesia, yang mengamanatkan kepada Negara untuk memajukan kebudayaan Indonesia (Pasal 32 ayat (1) UUD 45 mengamanatkan kepada Negara untuk memajukan kebudayaan Indonesia di tengah-tengah peradaban dunia). Sebelumnya, Pemerintah juga telah melakukan amandemen terhadap Undang-undang Hak Cipta (UU 28/14 tentang Hak Cipta)
Undang-undang Paten (UU 13/16 tentang Paten) dan Undang-undang Merek ( UU 20/16 tentang merek) sebagai bagian dari upaya memperbaiki sistem perlindungan kekayaan intelektual, tidak saja bagi bangsa Indonesia, tetapi juga bagi warga negara lain yang Negaranya menjadi anggota WTO, karena Pemerintahnya meratifikasi pembentukan organisasi perdagangan dunia tersebut (Lihat prinsip-prinsip utama dari kesepakatan pembentukan WTO pada tahun 1994. Indonesia meratifikasi Kesepakatan WTO dengan Undang-undang Nomor 7 Tahun 1994 tentang Persetujuan Pembentukan Organisasi Perdagangan Dunia). 
Pertanyaan dasarnya adalah bagaimana menyerasikan implementasi berbagai undang-undang tersebut agar terjadi sinergi yang menguntungkan bagi bangsa Indonesia, tidak saja dalam tataran pelaksanaan undang-undang secara hukum, tetapi justru agar tujuan intrinsic (teleological aspect) dari pembentukan dan pemberlakuan undang-undang tersebut dapat dicapai dengan sebaik-baiknya, secara efektif dan efisien.

Benarkah ada hubungan sinergis antara berbagai undang-undang di bidang HKI itu dengan diberlakukannya Undang-undang Pemajuan Kebudayaan? Jika benar, bagaimana melakukan langkah-langkah harmonis dalam mengimplementasikan berbagai undang-undang tersebut, agar bangsa Indonesia memperoleh manfaat dari keberlakukan undang-undang yang dimaksud?

Pertanyaan-pertanyaan di atas perlu mendapatkan jawaban yang akurat dan benar. Untuk itu perlu dilakukan kajian doctrinal agar diperoleh jawaban teoritis, yang pada gilirannya dapat dijadikan acuan atau pedoman pelaksanaan undangundang bagi aparatur birokrasi yang menjadi focal point dari undang-undang tersebut. Selain itu juga, agar anggota masyarakat juga memahami apakah kirakira manfaat yang dapat diperoleh dengan diberlakukannya undang-undang yang dimaksud.

Tentu saja kajian doctrinal dan jawaban teoritis tadi tidak akan berarti apa-apa jika tidak diikuti dengan saran implementasi yang bersifat "memberi pedoman dan solusi". Itu sebabnya secara metodologis, tulisan ini tidak saja melulu legal approach, tetapi juga mencoba memberikan jalan atau cara mewujudkan norma-norma dari undang-undang yang dibahas (prescriptive method).
Langkahnya diawali dengan mengkaji bunyi pasal-pasal dari undang-undang yang bersangkutan, dilanjutkan dengan interpretasi atas pasal-pasal yang dimaksud. Interpretasi tersebut dilakukan dengan menggunakan basis argument yang rasional, baik secara gramatikal, sistematikal, maupun historical.

Secara sistematik, pembahasan dimulai dengan upaya memahami apa yang diatur dan dimaksudkan dalam Undang-undang Pemajuan Kebudayaan, kemudian dilanjutkan dengan analisis berdasarkan perspektif perundang-undangan HKI, khususnya terhadap pasal-pasal yang terkait langsung dengan tujuan diberlakukannya Undang-undang Pemajuan Kebudayaan. Hasilnya dapat dikatakan sebagai upaya symphonizing IP Laws dalam pemajuan kebudayaan Indonesia, yang mungkin saja berguna bagi aparatur birokrasi yang bertanggung jawab terhadap eksekusi berbagai norma undang-undang yang dimaksud.

\section{METODOLOGI PENELITIAN}

Penelitian ini merupakan penelitian hukum normatif, yaitu penelitian yang didasarkan pada hukum sebagai kaidah. Oleh karena itu, kajian didasarkan pada prinsip, norma, dan doktrin. Penelitian ini menggunakan bahan hukum primer, berupa UUD 1945, UU No. 5 Tahun 2017, dan beberapa peraturan perundang-undangan lainnya, bahan hukum sekunder terdiri dari buku, jurnal dan hasil penelitian, dan bahan hukum tersier berupa kamus. Analisis data yang digunakan analisis data kualitatif yaitu analisis yang didasarkan pada datadata kualitatif yang dikaji, dianalisis dan disimpulkan kemudian disajikan sedemikian rupa. 


\section{HASIL DAN PEMBAHASAN}

\section{UU Pemajuan Kebudayaan dan HKI}

Undang-undang Pemajuan Kebudayaan disahkan pada tanggal 24 Mei 2017 dengan Nomor 5 Tahun 2017, dan diundangkan (enacted) pada tanggal 29 Mei 2017 dalam Lembaran Negara Tahun 2017 Nomor 104 (selanjutnya akan disingkat UUPK 2017). Tujuan diberlakukannya undang-undang ini adalah untuk: (1) mengembangkan nilainilai luhur budaya bangsa, memperkaya keberagaman budaya, (3) memperteguh jati diri bangsa, (4) memperteguh persatuan dan kesatuan bangsa, (5) mencerdaskan kehidupan bangsa, (6) meningkatkan citra bangsa, (7) mewujudkan masyarakat madani, (8) meningkatkan kesejahteraan rakyat, (9) melestarikan warisan budaya bangsa, dan (10) mempengaruhi arah peradaban dunia, sehingga kebudayaan menjadi haluan pembangunan nasional (Pasal 4 UU 5/17 ttg Pemajuan Kebudayaan).

Apa yang menjadi tujuan pemberlakukan undang-undang tersebut tentunya harus dijadikan patokan bagi Pemerintah (eksekutif) dan warga masyarakat secara keseluruhan dalam upaya mengembangkan, memanfaatkan, mempromosikan, dan melestarikan kebudayaan Indonesia. Keempatnya merupakan upaya yang juga sudah dibicarakan dalam rangkaian pertemuan di dalam forum WIPO, khususnya dalam Inter-Governmental Committee on Intellectual Property Rights and Geneteic Resources, Traditional Knowledge, and Folklore (selanjutnya akan disingkat IGC on GRTKF). Dengan kata lain, bahwa apa yang menjadi tujuan dari pemberlakuan UUPK 2017 sesungguhnya merupakan sebuah keniscayaan bagi sebuah bangsa dalam mempertahankan diri dari arus globalisasi, yang juga menjadi bagian penting dari upaya yang dilakukan oleh bangsa-bangsa di dunia untuk disepakati melalui forum PBB, khusus forum WIPO IGC-GRTKF.

Selanjutnya, apa yang menjadi objek pemajuan kebudayaan juga sudah ditetapkan di dalam UUPK 2017, yaitu: tradisi lisan, manuskrip, adat-istiadat, ritus, pengetahuan tradisional, teknologi tradisional, seni, bahasa, permainan rakyat, dan olah raga tradisional, atau yang secara singkat dapat disebut sebagai unsur kebudayaan (element of culture) (Pasal 5 UUPK 2017). Semuanya itu sejatinya adalah hasil cipta, rasa, karsa, dan karya manusia, yang dalam literature disebut sebagai kebudayaan (Pasal 1 butir (1) UUPK 2017) dan ( Koentjaraningrat: 1988).

Wujud dari hasil cipta, rasa, karsa, dan karya manusia dapat bermacam-macam. Ada yang berbentuk benda-benda tangible, ada pula yang berbentuk benda-benda intangible. Konsep-konsep HKI lebih banyak memfokuskan diri pada benda-benda intangible berupa hak dari manusiamanusia yang secara individual menghasilkan karya-karya kreatif. Sedangkan kebudayaan itu sendiri sejatinya adalah hasil karya manusia dalam sebuah kelompok tertentu, yang bisa saja dilingkupi oleh satuan wilayah tertentu atau etnik tertentu, yang dilakukan secara berulangulang dan turun temurun, yang kemudian dapat membentuk identitas tertentu. Salah satu contoh yang paling mudah diidentifikasi adalah bahasa. Bahasa adalah alat komunikasi yang dipergunakan oleh suatu kelompok masyarakat yang dilingkupi dalam satuan wilayah tertentu dan etnik tertentu yang kemudian menjadi identitas kelompok masyarakat tersebut. Misalnya Bahasa Jawa, Bahasa Sunda, Bahasa Cina, Bahasa Inggris, Bahasa Jerman, Bahasa Korea, Bahasa Jepang dan seterusnya. 
Penyebutan kata Jawa, Sunda, Cina, Inggris, dan Jerman adalah merujuk pada etnik group atau bangsa tertentu yang menggunakan bahasa yang bersangkutan. Bahwa kemudian ada bahasa yang dipergunakan oleh bangsa-bangsa di seluruh dunia, hal itu boleh jadi disebabkan karena pengaruh-pengaruh tertentu, seperti kolonisasi, perdagangan, politik, pendidikan, dan sebagainya.

Contoh lain yang lebih kompleks dalam mengidentifikasi objek pemajuan kebudayaan adalah pengetahuan tradisional. Pengetahuan ini dimiliki oleh manusia-manusia dalam suatu wilayah dan etnik tertentu yang dipraktekkan secara turun-temurun yang kemudian menjadi ciri dari kelompok masyarakat tersebut. Misalnya Subak, yaitu suatu penamaan dari pengetahuan tradisional masyarakat Bali dalam hubungannya dengan sistem pengairan sawah. Menyebut kata 'subak' tentu berhubungan dengan masyarakat yang mempraktekkan teknologi pengairan sawah, khususnya di daerah Bali. Orang yang mengetahui apa itu 'subak' tentu tidak akan mungkin mengatakan bahwa subak adalah Sunda, karena mereka tahu bahwa 'subak' adalah pengetahuan tradisional yang kemudian menjadi 'identitas' masyarakat Bali.

Objek pemajuan kebudayaan dalam perspektif HKI adalah kekayaan intelektual dalam arti luas, yang tidak dibatasi oleh konvensi-konvensi internasional (HKI konvensional) seperti paten, merek, desain industri, dan sebagainya. Dengan kata lain, objek pemajuan kebudayaan dalam perspektif HKI adalah karya intelektual dari kelompok-kelompok masyarakat yang lebih luas yang menjadi ciri atau identitas kelompok tersebut, atau dapat disebut sebagai HKI komunal, (sekadar untuk mempermudah penyebutannya saja guna membedakan dengan paten, merek, desain industry, dan sebagainya). Tentu harus dicatat bahwa objek pemajuan kebudayaan yang dimaksud dalam UUPK 2017 tidak terbatas pada HKI komunal saja, tetapi lebih luas dari itu. Pemajuan kebudayaan itu sendiri dimaknai sebagai "upaya meningkatkan ketahanan dan kontribusi budaya Indonesia di tengah peradaban dunia melalui perlindungan, pengembangan, pemanfaatan, dan pembinaan kebudayaan (Pasal 1 butir (3) UUPK 2017). Namun perlu dicatat pula bahwa upaya pemajuan kebudayaan itu boleh jadi menghasilkan karya intelektual yang dalam konsep HKI dapat diberikan perlindungan berdasarkan sistem HKI. Di sinilah sinergi perundang-undangan HKI dengan UUPK 2017 menjadi sangat penting.

\section{Langkah-langkah pemajuan kebudayaan}

\section{Inventarisasi}

Sebelum melakukan upaya pengembangan, pemanfaatan, pelestarian, dan promosi kebudayaan, terlebih dahulu harus dilakukan upaya mencatat dan mendokumentasikan apa saja yang menjadi objek pemajuan kebudayaan. Ini yang disebut inventarisasi unsur-unsur kebudayaan. Inventarisasi merupakan langkah penting agar dalam proses pemajuan kebudayaan dapat menghasilkan basis data yang pada gilirannya sangat berguna bagi upaya pelestariannya. Basis data juga sangat penting dalam perspektif HKI. Misalnya, dalam sistem pelindungan paten, peran prior arts. Prior arts dalam sistem paten dimaknai sebagai teknologi yang sudah terpublikasi, sebagai alat untuk mengukur atau menentukan apakah invensi yang diajukan permohonan paten masih dapat dikatakan baru atau tidak (Pasal 3 ayat (1) dan Pasal 5 ayat (1) UU Paten 2016 ttg peran prior arts dalam system perlindungan paten) sangat signifikan. Basis data merupakan sumber penting dalam 
mencari prior arts untuk keperluan research dan pemeriksaan permohonan paten. Dalam sistem perlindungan hak cipta, database dapat dijadikan sumber inspirasi dalam menciptakan karya-karya di bidang seni, sastra, dan ilmu pengetahuan.

Pertanyaannya, siapakah yang harus melakukan inventarisasi objek kebudayaan? Pasal 18 ayat (1) UUPK 2017 menegaskan bahwa 'setiap orang' dapat melakukan pencatatan dan pendokumentasian objek pemajuan kebudayaan. Ini berarti bahwa UU memberikan kebebasan kepada siapa saja untuk melakukan pencatatan dan pendokumentasi. Namun demikian, untuk menjamin bahwa apa yang dicatat dan didokumentasikan oleh 'setiap orang' itu adalah benar merupakan unsur kebudayaan dari kelompok masyarakat pengembannya, maka harus dilakukan verifikasi dan validasi bahwa hasil pencatatan dan pendokumentasian itu benar dan dapat dipertanggungjawabkan (Pasal 19 UUPK 2017) mengatur mengenai mekanisme validasi yang dimaksud dengan melalui proses penetapan yang didukung dengan berbagai persyaratan yang ditetapkan oleh Pemerintah berdasarkan kuasa undang-undang.

Inventarisasi itu sendiri terdiri dari 3 (tiga) kegiatan utama, yaitu: (1) pencatatan dan pendokumentasian, (2) penetapan, dan (3) pemutakhiran data (Pasal 16 ayat (1) UUPK 2017). Dengan demikian, inventarisasi adalah sebuah kegiatan yang dinamis. Hal itu sejalan dengan sifat dari unsur kebudayaan yang juga dinamis. Seluruh proses inventarisasi dilakukan melalui Sistem Pendataan Kebudayaan Terpadu (Pasal 16 ayat (2) UUPK 2017).
Meskipun pencatatan dan pendokumentasian dapat dilakukan oleh setiap orang, akan tetapi agar supaya ada kepastian bahwa ada pihak yang melakukan pencatatan dan pendokumentasian objek pemajuan kebudayaan, maka undang-undang membebankan kewajiban kepada Pemerintah, baik Pemerintah Pusat maupun Pemerintah Daerah untuk melakukan pencatatan dan pendokumentasian (Pasal 17 UUPK 2017). Setidak-tidaknya, ketika kegiatan tersebut dilakukan oleh Pemerintah, maka diharapkan akan tercipta satu sistem yang seragam dan terstandardisasi atas data kebudayaan yang terpadu. Pihak swasta yang akan melakukan kegiatan pencatatan dan pendokumentasian dapat mengacu pada sistem yang dikembangkan Pemerintah. Hal itu akan mempermudah proses verikasi dan validasi sebelum ditetapkan oleh Pemerintah.

Proses verifikasi dan validasi data tersebut harus diterapkan juga terhadap kegiatan pemutakhiran datanya, sehingga diharapkan data kebudayaan terpadu itu sendiri akan menjadi acuan standard dan valid mengenai data kebudayaan Indonesia. Data kebudayaan itu sendiri nantinya akan bermanfaat bagi orang-orang kreatif yang akan menghasilkan karya intelektual, baik di bidang seni, sastra, maupun ilmu pengetahuan, maupun di bidang teknologi. Semuanya itu sangat terkait dengan sistem hukum kekayaan intelektual, yang focus pada karya-karya individual dan "baru" (sekadar untuk membandingkannya dengan karya tradisional). Itu sebabnya simphonisasi pelaksanaan undang-undang pemajuan kebudayaan dengan undangundang di bidang HKI menjadi sebuah keniscayaan.

\section{Pengembangan (Development)}

UUPK 2017 memberi mandat kepada 
Pemerintah untuk melakukan kegiatan pengembangan unsur-unsur kebudayaan. Kegiatan yang sama juga terbuka bagi setiap orang untuk melakukan kegiatan pengembangan (Pasal 30 UUPK 2017). Kegiatan pengembangan itu sendiri dilakukan melalui upaya (1) menyebarluaskan (publishing or publication), (2) mengkaji atau meneliti (research and development), dan (3) pengayaan keberagaman (enrichment of diversity) unsur-unsur kebudayaan. Kegiatan penyebarluasan dimaksudkan agar kebudayaan tidak terkungkung hanya dalam wilayahnya sendiri. Kebudayaan harus dikenal oleh orang lain di luar wilayahnya. Syukur-syukur mampu mempengaruhi atau memberikan kontribusi kepada kemanusiaan. Sebagaimana "kebudayaan pop" yang sudah menyebar hampir ke seluruh dunia, maka jika ada kearifan yang terkandung di dalam kebudayaan Indonesia yang dapat memberikan kontribusi positif terhadap peradaban dunia, maka hal itu akan sangat berguna bagi kemanusiaan.

Research and development terhadap objek pemajuan kebudayaan sangat penting bagi upaya pemajuan kebudayaan itu sendiri. Misalnya, research and development yang dilakukan terhadap pengetahuan tradisional di bidang obat-obatan bukan tidak mungkin menghasilkan temuan baru di bidang farmasi. Jika ini terjadi, maka khasanah pengobatan tradisional akan berkembang dan memberikan sumbangan nyata bagi dunia kesehatan. Untuk ini, bahkan UU Paten 2016 telah memberikan ruang pengaturan berupa acknowledgement terhadap kearifan tradisional di bidang obat-obat. Pasal 26 ayat (1) UU Paten 2016 menegaskan bahwa: "jika invensi berkaitan dengan dan/atau berasal dari sumber daya genetic dan/atau pengetahuan tradisional, harus disebutkan dengan jelas dan benar asal sumber daya genetic dan/atau pengetahuan tradisional tersebut dalam deskripsi".

Ketentuan mengenai pengembangan ini sangat berkaitan dengan ketentuan mengenai kegiatan inventarisasi objek pemajuan kebudayaan. Untuk mengetahui bahwa suatu invensi berasal dari pengembangan pengetahuan tradisional, maka sudah dapat dipastikan bahwa basis data tentang pengetahuan tradisional menjadi sebuah keharusan. Tanpa basis data tidak mungkin dapat dilakukan pembuktian bahwa suatu invensi adalah berasal dari pengembangan pengetahuan tradisional. Dengan kata lain, pelaksanaan kegiatan inventarisasi objek pemajuan kebudayaan berkaitan langsung dengan pelaksanaan UU Paten 2016. Itulah sebabnya symphony antara pelaksanaan UUPK 2017 dengan UU di bidang HKI menjadi sebuah keniscayaan.

Selanjutnya, mengenai kegiatan enrichment of diversity, ia merupakan upaya memelihara keanekaragaman kebudayaan di Indonesia. Sebagaimana kenyataan bahwa di Indonesia terdapat berbagai macam suku bangsa, maka sudah sepatutnya pula keanekaragaman budaya menjadi kenyataan yang tak terbantahkan. Namun demikian, pengayaan (enrichment) juga berarti memperkaya ragam budaya melalui proses asimilasi, akulturasi, adaptasi, dan inovasi. Hanya dengan cara demikian, maka kebudayaan menjadi semakin dinamis dalam mengikuti perkembangan jaman, termasuk dalam mengikuti perkembangan ilmu dan teknologi. Mungkin kurang baik ketika ilmu pengetahuan di bidang pengobatan sudah berkembang sedemikian rupa, sementara itu masyarakat masih menggunakan system pengobatan berbasis takhayul, Misal adanya kepercayaan bahwa seseorang sakit karena kesurupan, dan dilakukan pengobatan dengan cara-cara mengusir jin, dan 
sebagainya dan sejenisnya. Kebudayaan juga tidak tertutup dari upaya inovasi.

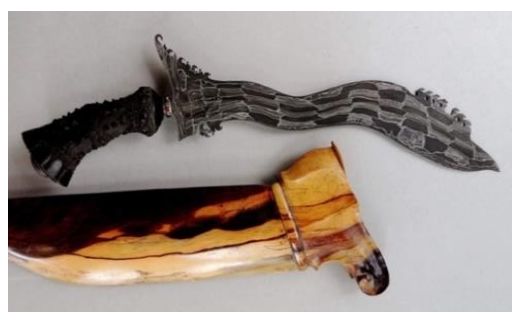

Jangker, karya Hardi

Sekadar contoh, saya ingin menyampaikan sebuah karya seni yang relatif baru, yang disebut 'Jangker'. Jangker adalah singkatan dari Kujang dan Keris. Ia merupakan gabungan dari desain seni tradisi tanah Sunda (Kujang) dan Jawa (Keris). Walaupun keris juga sesungguhnya sudah dibuat di berbagai daerah lain di tanah Nusantara. Berbagai desain keris juga ditemukan di berbagai wilayah di Nusantara ini. Lihat Desain tradisi kebudayaan Sunda diletakkan di ujung jangker. Sementara itu desain tadisi Keris diletakkan di bagian pangkal jangker. Ketika kedua desain ini digabung, ternyata menghasilkan satu jenis karya baru. Karya ini tentu saja dapat dilindungi dengan system HKI yang individual, karena pada kenyataannya jangker ini diciptakan desainnya oleh seorang seniman bernama Hardi. Namun karena desain berbasis tradisi Sunda dan Jawa tetap diletakkan hampir secara utuh, meski dengan format baru, maka ia juga dapat dimaknai sebagai pengembangan dari seni tradisi. Kiranya, jangker juga dapat disebut sebagai hasil dari upaya pengembangan dalam bentuk pengayaan (enrichment) dari desain seni tradisi tersebut.

Jangker merupakan satu bentuk inovasi di bidang desain senjata tradisional, yang juga dapat memperkaya bentuk-bentuk kebudayaan yang bersangkutan. Dengan demikian, upaya memperkaya objek pemajuan kebudayaan pada hakikatnya juga mengembangkan kebudayaan itu sendiri agar bertahan dalam arus global yang juga membawa kebudayaan dari masyarakat yang berinteraksi dalam ranah pergaulan antar bangsa.

Sistem HKI juga mempunyai kontribusi dalam rangka memperkaya objek-objek pemajuan kebudayaan. Musik-musik tradisional dapat menjadi lebih indah dan menarik untuk dinikmati ketika dilakukan inovasi atau pencampuran jenis-jenis instrument untuk memainkannya. Contoh, pementasan Megalitikum Kuantum pada hari ulang tahun Kompas ke-40 yang digagas Rizaldi Siagian adalah merupakan salah satu bentuk inovasi dalam performing traditional arts

(lihat:

http://www.unisosdem.org/article detail.php? aid $=5082 \&$ coid $=3 \&$ caid $=31 \&$ gid $=$ 2.)

Dengan melakukan inovasi, bukan tidak mungkin seseorang seperti Rizaldi justru mendapat kesempatan memperoleh perlindungan $\mathrm{HKI}$, walaupun dalam sistem pemajuan kebudayaan orang tersebut tetap dikenakan kewajiban untuk menyebut sumbernya, sebagaimana contoh dalam Pasal 26 UU Paten 2016 tersebut di atas.

\section{Pemanfaatan (Utilization)}

UUPK 2017 membuka peluang seluasluasnya bagi anggota masyarakat di Indonesia untuk memanfaatkan objek pemajuan kebudayaan. Dalam contoh pengetahuan tradisional di bidang pengobatan, setiap warga Negara Indonesia diberi kesempatan seluas-luasnya untuk melakukan penelitian berbasis pengetahuan tersebut, yang pada gilirannya dapat menghasilkan invensi yang patentable. Hanya saja ketika invensi tersebut hendak dimintakan perlindungan paten, maka 
inventor atau pemohonnya harus menyebutkan asal-usul invensinya (Pasal 26 ayat (1) UU Paten 2016). Dalam bidang seni, setiap orang diberi kesempatan untuk memanfaatkan seni tradisi sebagai bahan baku karya kreatifnya dalam dunia modern. Salah satu contoh yang ada di Indonesia adalah musisi Dwiki Dharmawan, yang menggunakan musik tradisional sebagai sumber inspirasi dalam menciptakan karya kreatifnya di bidang musik. Bahkan dengan itu, Dwiki telah berhasil melanglang buana dengan membawa seni musik tradisional Indonesia menjadi bagian dari world music (Lihat:

https://id.wikipedia.org/wiki/Dwiki_Dhar mawan).

UUPK 2017 membuka kesempatan yang luas kepada masyarakat untuk menjadikan objek pemajuan kebudayan sebagai sumber dalam membuat produk. Dalam contoh obat tradisional, pengetahuan dari masyarakat pengemban, Istilah masyarakat pengemban (custodian) merujuk pada kelompok masyarakat tradisional yang menjadi pemilik atau pemegang hak dari ekspresi kebudayaan yang menjadi jati diri mereka. Dalam konteks benefit sharing atas pemanfaatan (utilization) objek pemajuan kebudayaan, masyarakat pengemban adalah penerima manfaat dari benefit sharing setelah adanya pemanfaatan (utilization) objekobjek pemajuan kebudayaan. Lihat naskah Rancangan Undang-undang tentang Pengetahuan Tradisional dan Ekspresi Budaya Tradisional inisiatif Dewan Perwakilan Daerah Republik Indonesia (DPD RI) dapat dijadikan bahan baku atau sumber informasi dalam melakukan penelitian kefarmasian, yang pada giliran dapat menghasilkan produk-produk farmasi, bahkan yang berbasis paten. Dalam contoh seni tradisi, kesenian masyarakat pengemban dapat dijadikan bahan atau sumber inspirasi dalam menciptakan karya baru, yang boleh jadi berpeluang untuk mendapatkan perlindungan Hak Cipta. Hanya saja penggunaan objek pemajuan kebudayaan itu harus dilakukan dengan tidak merusak nilai luhur dan kearifan yang terkandung di dalam seni tradisi itu sendiri. Selain itu, pemanfaatan yang dilakukan oleh perusahaan-perusahaan besar atau pihak asing harus dilakukan dengan terlebih dahulu mendapatkan ijin dari otoritas public. Ijin dapat diberikan, jika dalam upaya pemanfaatan itu dipenuhi syarat: (1) memiliki persetujuan atas dasar informasi awal (prior inform consent); (2) ada system pembagian manfaat (sharing of benefit arising from the utilization); (3) mencantumkan asal-usul objek pemajuan kebudayaan (acknowledgement)(Pasal 37 UUPK 2017).

\section{Promosi (Promotion)}

Promosi adalah upaya untuk memperkenalkan kebudayaan Indonesia kepada dunia. Sebagaimana promosi dalam dunia perdagangan yang dimaksudkan untuk menarik minat pembeli terhadap produk yang ditawarkan, promosi kebudayaan Indonesia dilakukan agar kebudayaan Indonesia dikenal oleh bangsabangsa lain di dunia, yang pada gilirannya akan melahirkan ketertarikan. Ketertarikan yang dalam akan melahirkan kecintaan. Kecintaan akan melahirkan penghormatan atau penghargaan (respect) dan mungkin juga penggunaan produk-produk berbasis warisan budaya itu.

Ketika bangsa-bangsa di dunia menggemari hasil kebudayaan Indonesia, bukan tidak mungkin pada akhirnya unsur kebudayaan itu akan berkembang sedemikian rupa, yang dalam ranah bisnis akan menjadi produk unggulan bangsa Indonesia. Sebagai produk unggulan, ia memiliki daya saing tinggi, justru karena keunikan dan kualitas produk 
yang bersangkutan.

Pemerintah Indonesia bahkan telah membentuk suatu lembaga nonkementerian, yang ditugaskan untuk mempromosikan kreativitas anak bangsa melalui kebijakan-kebijakan di bidang ekonomi kreatif, yang pada gilirannya akan memberikan kontribusi pendapatan yang selalu meningkat terhadap PDB nasional

(Lihat: http://www.bekraf.go.id/profil/tugas).

Jika kreativitas anak bangsa didasarkan pada atau bersumber pada warisan budaya bangsa, maka produk yang akan dihasilkan juga akan memiliki daya saing karena keunikan dari produk yang bersangkutan. Jika produk-produk tersebut digarap dengan kualitas yang baik, bukan tidak mungkin produk itu akan digemari oleh bangsa-bangsa lain.

\section{Pelestarian (Preservation)}

UUPK 2017 menggunakan istilah pemeliharaan untuk memberi arti pada upaya pelestarian. Pasal 24 ayat (3) UUPK 2017 menegaskan bahwa pemeliharaan objek pemajuan kebudayaan dilakukan untuk mencegah kerusakan, hilang atau musnahnya objek pemajuan kebudayaan. Artinya, pelestarian adalah upaya mencegah punahnya kebudayaan suatu kelompok etnik tertentu. Ada sebuah contoh yang menarik, sekaligus memilukan. Ketika projek Megalitikum Kuantum dikerjakan, Rizaldi melakukan perekaman atas performance dari seni musik dan tari Hoho dari masyarakat Nias. Video tentang music dan tari Hoho dalam projek Megalitikum Kuantum dapat dilihat pada saat perayaan ulang tahun Kompas yang ke-40. Sayangnya rekaman video tersebut saat ini sulit didapatkan. Penulis memiliki rekaman video Megalitikum Kuantum dalam bentuk softcopy yang tersimpan dalam hard disk. Tidak lama setelah proses perekaman selesai, terjadilah bencana tsunami yang dahsyat pada tanggal 26 Desember 2004. Pada bencana itu, beberapa seniman tradisional yang terlibat dalam proses perekaman seni Hoho tersebut menjadi korban tewas. Bayangkan jika proses perekaman belum dilakukan, dan para pelaku seni tersebut tidak eksis lagi, apakah itu tidak berarti kepunahan seni yang bersangkutan? Itu sebabnya pencatatan dan pendokumentasian menjadi bagian yang sangat penting dalam upaya pelestarian.

UUPK 2017 mewajibkan Pemerintah untuk melakukan upaya pelestarian atau pemeliharaan. Begitu juga masyarakat luas diberikan kesempatan pula untuk ikut aktif melakukan upaya pelestarian terhadap objek-objek pemajuan kebudayaan (Pasal 24 ayat (1) dan (2) UUPK 2017). Upaya pelestarian meliputi kegiatan-kegiatan sebagai berikut (Pasal 24 ayat (4) UUPK 2017) :

Menjaga nilai keluhuran dan kearifan objek pemajuan kebudayaan;

a. Menggunakan objek pemajuan kebudayaan dalam kehidupan seharihari;

b. Menjaga keanekaragaman objek pemajuan kebudayaan;

c. Menghidupkan dan menjaga ekosistem kebudayaan;

d. Mewariskan objek pemajuan kebudayaan kepada generasi berikutnya.

Pelestarian kebudayaan juga dapat dilakukan melalui kegiatan penyelamatan objek-objek pemajuan kebudayaan, yang antara lain dapat dilakukan melalui kegiatan revitalisasi (UU 11/10 ttg Cagar Budaya ) (UU Cagar Budaya 2010) diartikan sebagai "kegiatan pengembangan yang dimaksudkan untuk menumbuhkan kembali nilai-nilai penting cagar budaya dengan penyesuaian fungsi baru yang tidak 
bertentangan dengan prinsip pelestarian dan nilai budaya masyarakat". (Pasal 1 butir (31) UU Cagar Budaya 2010). repatriasi, dan restorasi. Contoh kegiatan revitalisasi yang menarik untuk disimak adalah pendidikan atau pengajaran membaca huruf asli bahasa Bugis. Kegiatan ini muncul ketika Theatre I La Galigo dipentaskan. Theatre I La Galigo itu sendiri diciptakan oleh Robert Wilson dari Amerika Serikat berbasis kitab yang dianggap sakral oleh orang Bugis (Lihat: http://nationalgeographic.co.id/berita/20 12/06/la-galigo-kitab-sakral-orangbugis).

Peristiwa tersebut sempat menimbulkan kontroversi tentang kebolehan orang asing mementaskan epic La Galigo, walaupun kemudian mereda. Namun dari peristiwa tersebut terdapat hikmah yang baik, yaitu munculnya kegairahan dari masyarakat setempat untuk kembali mengajarkan cara membaca huruf-huruf Bugis yang terdapat di dalam Kitab tersebut. Pelajaran itu diberikan kepada anak-anak kecil di lingkungan masyarakat Bugis di daerah Sulawesi Selatan. Kegiatan ini merupakan upaya revitalisasi dari penggunaan huruf asli dari bahasa Bugis melalui pengajaran kembali huruf dan bahasa Bugis kepada anak-anak kecil, yang boleh jadi tidak mengenal lagi huruf-huruf asli bahasa lokal tersebut.

Repatriasi adalah upaya mengembalikan benda-benda budaya yang tersimpan di berbagai Negara untuk dikembalikan ke masyarakat pengembannya atau sekurang-kurangnya ke museum-museum setempat. Sedangkan restorasi adalah upaya memperbaiki peninggalan warisan budaya yang boleh jadi rusak karena cuaca atau karena sebab-sebab lain. Semua kegiatan tersebut pada hakikatnya merupakan upaya melestarikan objekobjek pemajuan kebudayaan dan melestarikan kebudayaan itu sendiri.

\section{Peran Hukum Kekayaan Intelektual Dalam Pemajuan Kebudayaan}

UUPK 2017 tidak saja meletakkan beban kewajiban kepada Pemerintah sebagai eksekutif untuk mengambil langkahlangkah penting dalam melaksanakan undang-undang tersebut. UUPK 2017 juga mengajak semua warga bangsa untuk berpartisipasi dalam memajukan kebudayaan Indonesia. Ajakan itu berupa pemberian kesempatan yang seluas-luasnya bagi warga bangsa untuk melakukan kegiatan, antara lain:

1) melakukan pencatatan dan pendokumentasian semua unsur kebudayaan yang mejadi sasaran utama pemajuan kebudayaan (Pasal 1 butir (8) jo 18 ayat (1) UUPK 2017).

2) melakukan pemutakhiran data kebudayaan (Pasal 20 ayat (2) UUPK 2017).

3) mencegah klaim HKI dari perusahaanperusahaan besar dan pihak asing yang memanfaatkan objek kebudayaan tanpa prior inform consent and sharing of benefit arising from the utilization of Indonesian cultural heritage (Pasal 22 (3) jo Pasal 37 ayat (1) \& (2) UUPK 2017). Elements of Indonesian culture adalah semua bentuk atau wujud hasil kebudayaan dari semua kelompok masyarakat atau ethnic groups yang hidup di dalam wilayah Negara RI dan unsur kebudayaan dari kelompok masyarakat ini yang diekspresikan di luar wilayah Indonesia. Contoh yang paling konkrit adalah ketika Negeri jiran mengklaim beberapa unsur kebudayaan Indonesia sebagai kebudayaan mereka.

4) mencegah unsur2 kebudayaan dari kerusakan atau kepunahan, termasuk melakukan semua kegiatan 
pemeliharaan, seperti menjaga nilai luhur kebudayaan, melakukan inovasi terhadap unsur-unsur kebudayaan, dan bahkan menggunakan unsurunsur kebudayaan itu sendiri dalam kehidupan sehari-hari, misalnya mengembangkan seni batik dan menggunakan batik sebagai pakaian sehari-hari, dan mewariskan semua unsur kebudayaan kepada generasi berikutnya (Pasal 24 ayat (3) UUPK 2017).

5) melakukan kegiatan revialisasi, repatriasi, dan restorasi atas semua unsur-unsur kebudayaan (Pasal 26 ayat (3) UUPK 2017).

6) melakukan kegiatan pengembangan (development) unsur-unsur kebudayaan, seperti penelitian, dan inovasi. Hasilnya disebarluaskan agar public mengetahui bahwa terdapat unsur baru dari suatu kebudayaan yang telah dikembangkan melalui langkah inovatif (Pasal 30 ayat (3) UUPK 2017).

7) memanfaatkan unsur-unsur kebudayaan dalam rangka membangun karakter bangsa, meningkatkan ketahanan budaya, meningkatkan kesejahteraan masyarakat, meningkatkan peran aktif dalam hubungannya dengan dunia internasional, baik dalam sektor ekonomi atau pun dalam komunikasi lintas budaya dan kolaborasi antarbudaya, (Pasal 32 \& 33 UUPK 2017).

Semua kegiatan yang dilakukan oleh individu dalam rangka pemajuan kebudayaan mengandung potensi HKI. Sebut saja kegiatan pencatatan dan pendokumentasian. Kegiatan ini pada ujungnya dapat melahirkan database yang sangat penting bagi pemajuan kebudayaan. Database itu sendiri dalam system yang diadopsi oleh hak cipta merupakan objek perlindungan hak cipta (Pasal 40 ayat (1) UU Hak Cipta 2014 ). Suatu database yang bagus dan telah diverifikasi dan divalidasi akan mempunyai nilai ekonomi yang sangat tinggi, karena kontennya dapat digunakan sebagai sumber inspirasi untuk melakukan kegiatan inovatif dan kreatif dalam mengembangkan unsurunsur kebudayaan.

Selanjutnya, pengembangan unsur-unsur kebudayaan itu sendiri juga dapat menghasilkan kreasi-kreasi baru atau invensi di bidang teknologi yang berpotensi menghasilkan invensi yang patentable. Misalnya penelitian terhadap tanamantanaman obat yang diketahui telah digunakan dalam pengobatan tradisional. Bukan mustahil bahwa dari penelitian tersebut ditemukan khasiat dari tanamantanaman tertentu yang pada akhirnya menghasilkan invensi di bidang farmasi yang bernilai ekonomi tinggi. Pasal 26 UU Paten 2016 membuka kemungkinan bagi inventornya untuk mendapatkan pelindungan paten, asalkan sebelum itu dilakukan disclosure of origin dan sesudahnya dilakukan pembagian manfaat jika pelindungan paten itu menghasilkan manfaat ekonomi yang tinggi. Tentu saja manfaat yang dimaksud di sini bukan hanya berupa pembagian laba (profit), tetapi dapat berbentuk manfaat lain yang justru lebih dibutuhkan bagi masyarakat pengembannya (Sardjono: 2010).

Selain daripada itu, dalam kegiatan pengayaan kebudayaan melalui inovasi kebudayaan juga dapat menghasilkan produk atau performance dari karya cipta anak bangsa yang juga bernilai tinggi. Desain baru dalam karya fashion yang menggunakan unsur-unsur kebudayaan tentu saja memiliki keunggulan dari keunikannya, karena keunikan itu tidak dimiliki bangsa lain. Di sinilah peran penting dari UUHC 2014 yang memberikan 
pelindungan bagi anak bangsa yang secara kreatif menghasilkan produk-produk berbasis warisan budaya.

Dalam skala yang lebih besar, pelindungan HKI konon dapat merangsang orang-orang kreatif untuk menghasilkan kreasi-kreasi baru yang dapat memberikan kontribusi dalam pengayaan unsur-unsur kebudayaan. Pernyataan ini didukung oleh para penganut reward theory yang antara lain dikemukakan oleh Richardson sebagai berikut:

"Economic development and social welfare will be advanced if rewards are given for the kinds of invention and creativity that result in new products, processes and services" (Richardson: 2001).

Dalam pernyataannya itu Richardson berpendapat bahwa perekonomian akan berkembang dan kesejahteraan social akan meningkat jika orang-orang kreatif diberi imbalan atas hasil invensi atau kreativitas mereka. Pemberian imbalan itu akan memotivasi orang kreatif lainnya untuk juga berkreasi guna menghasilkan manfaat ekonomi yang lebih besar, dan memberikan sumbangsih pada pertumbuhan ekonomi dan kesejahteraan social. Penganut reward theory mempercayai hal tersebut.

Dari paparan singkat di atas, kita dapat mengetahui bahwa ada hubungan sinergi yang kuat antara UUPK 2017 dengan berbagai undang-undang di bidang HKI, seperti UUHC 2014, UU Paten 2016, dan sebagainya. Namun demikian, hubungan sinergi itu hanya akan menjadi sebuah potensi yang kosong jika tidak dilakukan langkah-langkah strategis dan aksi-aksi yang nyata dalam implementasinya. Symphony yang indah akan terjadi ketika pelaksanaan UUPK 2017 didukung dengan pelaksanaan yang efektif dari UUHC 2014 dan UU Paten 2016 dan perundang- undangan HKI lainnya.

\section{UU Pemajuan Kebudayaan dalam Era Industry 4.00}

Era Industri 4.00 ditandai dengan disrupsi metode bisnis. Yang paling menonjol adalah model bisnis berbasis online. Gojek, Grab, Bukalapak, Traveloka, Amazon, Airbnb, dan lain-lainnya adalah contoh dari model bisnis di era digital. Semua itu diawali dan difasilitasi dengan munculnya perangkat ajaib bernama handphone, yang kemudian bergeser menjadi smartphone. Perangkat ini benar-benar mampu mengubah pola perilaku manusia dalam dunia konsumsi. Mulai dari konsumsi musik dan film hingga konsumsi pecel ayam sudah bisa diperantarai dengan alat kecil namun maha sakti itu.

Sesungguhnya, era disrupsi itu bukan hanya bersifat destruktif, merusak tatanan bisnis, dan membunuh berbagai pelaku bisnis yang mapan, seperti taksi, supermarket, bioskop, dan sebagainya. Tapi di dalam era industri 4.00 itu terdapat peluang bisnis yang luar biasa besarnya, justru bagi pelaku bisnis kecil-kecilan. Syaratnya adalah kreativitas. Contoh kecil saja, seorang produsen bantal sandaran untuk jok mobil atau bantal sandaran untuk di rumah dapat memanfaatkan peluang melalu Bukalapak, dsb. Mereka tinggal memproduksi barangbarang tersebut, untuk kemudian mendaftar sebagai pelapak guna memasarkan produk mereka. Tidak perlu investasi untuk membuka toko sendiri yang memang mahal biayanya.

Dalam dunia musik, meskipun digitalisasi musik telah berhasil mengeliminasi label industri karya rekaman yang selama ini menguasai pasar musik, namun pada kenyataannya telah memberikan peluang lebih besar bagi para pelaku musik. Mereka 
tidak lagi memerlukan perangkat rekaman yang canggih dan mahal yang dimiliki label rekaman. Mereka dapat merekam sendiri di rumah, karya-karya kreatif mereka. Kemudian mereka dapat memasarkan hasilnya melalui platform-platform digital yang tersedia di banyak tempat. Itulah peluang yang besar. Sayangnya, yang kemudian mampu mengantisipasi perubahan itu secara cepat adalah justru label-label rekaman tersebut. Mereka telah menggeser industri mereka yang semula berbasis teknologi analog, kini mereka telah menggeser metode bisnis mereka melalui platform digital.

Kiranya era digital ini telah membuka peluang besar bagi bisnis kriya, bisnis musik, dan jenis bisnis lainnya di Indonesia. Bisnis kriya adalah salah satu saja dari berbagai jenis bisnis berbasis cultural heritage. Para produsen patung Asmat sampai dengan produsen kain tenun di Sumatera Barat, dapat memanfaatkan lapak yang disediakan Bukalapak untuk menawarkan produknya. Para pembantik klasik di Jogja sampai pembatik kontemporer di Pekalongan dapat memajang dagangannya di dunia maya. Para petani kopi pilihan hingga produsen keripik singkong pun dapat memanfaatkan peluang bisnis online tersebut. Intinya, kreativitas menciptakan produk-produk unggulan makin mendapatkan jalur distribusi dan penjualan yang rendah biaya namun luas jangkauan pasarnya. Syaratnya tidak banyak, hanya butuh kreativitas dan kemauan.

Kreativitas dan kemauan secara alamiah mungkin dimiliki oleh kaum milenial. Mereka lebih mudah beradaptasi dengan dunia digital dibanding generasi baby boomer, yang cenderung gagap teknologi. Bahkan cucu saya yang baru berumur 5 tahun sudah sangat terampil menggunakan smartphone. Dengan sentuhan kreativitas dan dorongan motivasi yang kuat kepada generasi milenial ini, tampaknya mereka akan mampu menghasilkan karya-karya kreatif berbasis cultural heritage, yang unique dan tersebar di seantero Nusantara.

Dalam konteks itulah, UU Pemajuan Kebudayaan memiliki relevansi yang kuat. UU ini telah membuka akses dunia bisnis untuk memanfaatkan warisan budaya yang melimpah di tanah Nusantara. Sinergi antara perundang-undangan di bidang HKI dengan UU Pemajuan Kebudayaan akan mendorong kreativitas berbasis warisan budaya untuk tampil di pasar global. Platform digital telah memberikan jalan mulus bagi insan kreatif untuk memanfaat semua itu. Dan itu pula yang menjadi peluang bagi generasi milenial atau generasi Zee (Generasi Zee adalah sebutan untuk mereka yang lahir setelah pergantian abad di awal tahun 2000 ke depan).

\section{Langkah penting yang harus dilakukan}

UUPK 2017 menempatkan kewajiban yang lebih besar kepada Pemerintah, baik pusat maupun daerah untuk melakukan langkah konkrit, teutama dalam rangka inventarisasi, pengembangan, pemanfaatan, pelestarian, dan promosi objek-objek pemajuan kebudayaan. Pasal 43 dan 44 UUPK 2017 sudah dengan tegas menyebutkan apa saja yang menjadi tugas Pemerintah Pusat dan Pemerintah Daerah.

Tugas-tugas itu antara lain:

1) menjamin kebebasan berekspresi

2) menjamin pelindungan atas ekspresi budaya

3) melaksanakan pemajuan kebudayaan

4) memelihara kebinekaan

5) mengelola informasi di bidang kebudayaan 
6) menyediakan sarana dan prasarana kebudayaan

7) menyediakan sumber pendanaan untuk pemajuan kebudayaan

8) mendorong peran aktif dan inisiatif masyarakat dalam pemajuan kebudayaan

9) menggunakan kebudayaan sebagai salah satu media diplomasi internasional

10) meningkatkan kerja sama internasional di bidang kebudayaan, dan

11) menghidupkan dan menjaga ekosistem kebudayaan yang berkelanjutan

Semua tugas yang diamanatkan oleh undang-undang kepada Pemerintah menjadi acuan utama dalam menentukan langkah-langkah eksekusi di lapangan. Beberapa di antaranya bersifat sangat konkrit. Misalnya, tugas untuk melaksanakan pemajuan kebudayaan. Sebagaimana sudah disinggung di atas, pemajuan kebudayaan itu meliputi kegiatan inventarisasi, pengembangan, pemanfaatan, pelestarian, dan promosi kebudayaan. Dalam pelaksanaannya tentu harus melibatkan anggota masyarakat, yang bahkan sudah ditetapkan pula sebagai salah satu tugas yang harus dijalankan Pemerintah.

Pelibatan anggota masyarakat boleh jadi melahirkan karya-karya kreatif individual yang berpotensi HKI. Itu berarti bahwa focal point dari implementasi UUPK 2017 tidak saja diembankan kepada Kementerian atau lembaga yang mengurus kebudayaan, melainkan juga Kementerian atau lembaga yang mengurus berbagai kegiatan berkenaan dengan kreativitas, industri, perdagangan, pelindungan hak, khususnya hak kekayaan intelektual, dan sebagainya. Dengan demikian, kerja Pemerintah dalam projek pemajuan kebudayaan harus menjadi symphony yang harmonis di antara kementerian dan lembaga non-kementerian. Sebagai sebuah symphony, diharapkan akan terjadi kekompakan dalam memainkan orchestra pemajuan kebudayaan. Kementerian atau lembaga yang dimaksud antara lain: Kementerian Pendidikan dan Kebudayaan, Kementerian Perindustrian, Kementerian Perdagangan, Kementerian Hukum dan HAM, serta Badan Ekonomi Kreatif.

Salah satu tugas yang diembankan kepada Pemerintah c.q. kementerian dan lembaga tersebut di atas adalah: menyediakan sumber pendanaan untuk kegiatan pemajuan kebudayaan (Pasal 48 ayat (1) UUPK 2017) Ini berarti bahwa sejak diundangkannya UUPK 2017, semua kementerian tersebut di atas wajib melakukan perencanaan dan pengalokasian anggaran yang bersumber pada APBN (Anggaran Pendapatan dan Belanja Negara) (Pasal 48 ayat (2) UUPK 2017). Tentu saja dalam perencanaan dan pengalokasian anggaran harus melibatkan Kementerian Keuangan, yang bertanggung jawab terhadap masalah budgeting dalam pengelolaan keuangan Negara. Jika ada kementerian yang tidak melakukan langkah-langkah perencanaan dan pengalokasian anggaran untuk kegiatan pemajuan kebudayaan, maka dapat dikatakan bahwa kementerian tersebut mengabaikan undang-undang yang seharus dilaksanaan oleh kementerian sebagai bagian dari executive body. Bahkan undangundang telah mengamanatkan secara lebih konkrit terkait pendanaan, yaitu: membentuk dana perwalian kebudayaan (Pasal 49 ayat (1) UUPK 2017).

Pendanaan tersebut digunakan tidak saja bagi kegiatan Pemerintah dalam melaksanakan sendiri kegiatan pemajuan kebudayaan, melainkan juga digunakan dalam rangka memberikan fasilitas kepada 
anggota masyarakat yang berinisiatif melakukan kegiatan pemajuan kebudayaan. Walaupun undang-undang tidak membatasi bahwa pendanaan hanya bersumber pada APBN, tetapi setidaknya dengan APBN terdapat kepastian bahwa kegiatan pemajuan kebudayaan akan didukung dengan pendanaan yang bersumber dari keuangan Negara.

Tentu saja tidak tertutup kemungkinan bahwa dana dari masyarakat justru lebih besar. Apalagi jika kegiatan pemajuan kebudayaan itu didukung dengan investasi swasta yang memadai. Sebagai contoh, kegiatan pemanfaatan warisan budaya dalam industri kreatif tentu harus dilakukan dengan berbasis investasi. Di sinilah peran Kementerian Perindustrian, Kementerian Perdagangan, dan Badan Ekonomi Kreatif sangat dibutuhkan. Beberapa kementerian tersebut dapat memfasilitas proyek-proyek pemajuan kebudayaan yang berorientasi pada kegiatan industri dan perdagangan. Sementara itu, Kementerian Hukum dan HAM, khususnya Direktorat Jenderal Kekayaan Intelektual dapat memfasilitasi perolehan HKI bagi industri kecil dan menengah dalam negeri yang bidang usahanya berbasis pemanfaatan warisan budaya dan industri kreatif.

Salah satu contoh dalam industri berbasis warisan budaya adalah industri batik. Selama ini industri ini ditopang dengan bahan baku import, seperti kain dan zatzat pewarna sebagai bagian penting dari pengembangan dan pemanfaatan unsur kebudayaan berupa seni batik. Kondisi ini membuat industri batik sangat bergantung pada produk import. Selain itu, zat-zat pewarna import yang pada umumnya berbahan baku kimia juga menghasilkan limbah yang mencemari lingkungan. Padahal pada masa yang lalu, pewarnaan batik menggunakan bahan pewarna alam, yang berasal dari tanaman-tanaman tertentu. Alangkah baiknya, jika Pemerintah mengembalikan nature dari seni batik yang akrab dengan alam. Dalam hal ini Pemerintah dapat menginisiasi penyediaan bahan baku bagi industri batik berupa dukungan penuh bagi projek-projek investasi dalam industri kain mori (Kain mori adalah kain putih polos yang menjadi bahan baku utama kain batik) dan projek pertanian untuk tanaman yang menghasilkan zat pewarna serta dukungan terhadap industri manufaktur penghasil zat pewarna itu sendiri. Hanya dengan cara demikian, industri batik akan menjadi industri yang mandiri, tidak bergantung pada produk import.

Tentu saja investasi jenis ini kurang menarik bagi investor yang menginginkan profit yang besar dalam waktu singkat. Perilaku bisnis akan selalu demikian. Oleh sebab itu, projek pengembangan industri batik yang mandiri harus menjadi kewajiban Pemerintah untuk mewujudkannya. Kiranya UUPK 2017 sudah memberikan jalan keluar bagi Pemerintah untuk mulai menggarap industri berbasis warisan budaya yang mandiri dan menghasilkan produk unggulan bagi Negeri ini. Jika selama ini Pemerintah merasa tidak memiliki basis hukum untuk mengalokasikan anggaran guna pemajuan kebudayaan, maka dengan diberlakukannya UUPK 2017, Pemerintah sudah tidak bisa mengelak lagi untuk melaksanakan mandat Konstitusi, yaitu: memajukan kebudayaan Indonesia.

\section{KESIMPULAN}

Statement terakhir dalam paragraf sebelumnya adalah statement terpenting bahwa Pemerintah tidak dapat mengelak lagi dari kewajibannya berdasarkan UUD 45 untuk memajukan kebudayaan. Symphonizing IP in the advancement of 
culture harus menjadi projek besar yang dibebankan kepada Pemerintah untuk menjalankannya. Konsep HKI yang selama ini ditujukan untuk memberikan reward kepada orang-orang kreatif mendapatkan momentum dengan diundangkannya UUPK 2017. Hal itu dapat diwujudkan jika Pemerintah dan masyarakat berpadu dalam orchestra yang harmonis dalam melaksanakan perundang-undangan tersebut. Semoga.

\section{DAFTAR PUSTAKA}

BEKRAF. Juli 12 , 2017. http://www.bekraf.go.id/profil/tugas.

Dharmawan, Dwiki. Pasar Klewer. Juli 12 , 2017.https://id.wikipedia.org/wiki/Dwiki_Dh armawan.

Koentjaraningrat. (1998). Manusia dan Kebudayaan di Indonesia. Jakarta : Djembatan.

La Galigo Kitab Sakral orang Bugis. Juli 12 2017.http://nationalgeographic.co.id/berita/2 012/06/la-galigo-kitab-sakral-orang-bugis.

Megalitikum Kuantum, Upaya Menemukan Kembali Indonesia. Juli 12 , 2017. http://www.unisosdem.org/article detail.php? aid $=5082 \&$ coid $=3 \&$ caid $=31 \&$ gid $=2$.

Pasal 32 ayat (1) UUD 45 mengamanatkan kepada Negara untuk memajukan kebudayaan Indonesia di tengah-tengah peradaban dunia.

Pasal 4 UU No. 5 Tahun 2017 tentang Pemajuan Kebudayaan.

Pasal 5 Tahun 2017 tentang Pemajuan Kebudayaan.
Pasal 1 butir (1) Tahun 2017 tentang Pemajuan Kebudayaan.

Pasal 16 ayat (1) Tahun 2017 tentang Pemajuan Kebudayaan.

Pasal 16 ayat (2) Tahun 2017 tentang Pemajuan Kebudayaan.

Pasal 16 ayat (1) Tahun 2017 tentang Pemajuan Kebudayaan.

Pasal 16 ayat (2) Tahun 2017 tentang Pemajuan Kebudayaan.

Pasal 1 butir (8) jo 18 ayat (1) Tahun 2017 tentang Pemajuan Kebudayaan.

Pasal 20 ayat (2) Tahun 2017 tentang Pemajuan Kebudayaan.

Pasal 24 ayat (3) Tahun 2017 tentang Pemajuan Kebudayaan.

Pasal 26 ayat (3) Tahun 2017 tentang Pemajuan Kebudayaan.

Pasal 30 ayat (3) Tahun 2017 tentang Pemajuan Kebudayaan.

Pasal 32 \& 33 Tahun 2017 tentang

Pemajuan Kebudayaan.

Pasal 40 ayat (1) UU Hak Cipta 2014

Pasal 22 ayat (3) jo Pasal 37 ayat (1) \& (2) UUPK 2017

Pasal 24 ayat (3) Tahun 2017 tentang Pemajuan Kebudayaan.

Pasal 26 ayat (3) Tahun 2017 tentang Pemajuan Kebudayaan.

Pasal 30 ayat (3) Tahun 2017 tentang Pemajuan Kebudayaan. 
Pasal 30 Tahun 2017 tentang Pemajuan

Kebudayaan.

Pasal 32 \& 33 Tahun 2017 tentang

Pemajuan Kebudayaan.

Pasal 40 ayat (1) UU Hak Cipta 2014.

Pasal 1 butir (3) Tahun 2017 tentang Pemajuan Kebudayaan.

Pasal 19 Tahun 2017 tentang Pemajuan Kebudayaan.

Pasal 17 Tahun 2017 tentang Pemajuan

Kebudayaan.

Pasal 26 ayat (1) UU Paten 2016.

Pasal 19 Tahun 2017 tentang Pemajuan Kebudayaan,

Pasal 17 Tahun 2017 tentang Pemajuan

Kebudayaan.

Pasal 26 ayat (1) UU Paten 2016.

Pasal 1 butir (31) UU Cagar Budaya 2010

Pasal 24 ayat (1) dan (2) Tahun 2017 tentang Pemajuan Kebudayaan.

Pasal 24 ayat (4) Tahun 2017 tentang Pemajuan Kebudayaan.

Pasal 26 ayat (1) UU Paten 2016.

Pasal 3 ayat (1) dan Pasal 5 ayat (1) UU Paten 2016 menegaskan tentang peran prior arts dalam system perlindungan paten.

Pasal 48 ayat (1) Tahun 2017 tentang Pemajuan Kebudayaan.

Pasal 48 ayat (2.a \& b) Tahun 2017

tentang Pemajuan Kebudayaan.
Pasal 49 ayat (1) Tahun 2017 tentang

Pemajuan Kebudayaan.

Pasal 37 Tahun 2017 tentang Pemajuan Kebudayaan.

Richardson, Benjamin J. (2001). Indigenous Peoples, International Law and Sustainability, (Blackwell Publishers Ltd.), 9.

Sardjono, Agus. (2010). Hak Kekayaan Intelektual dan Pengetahuan Tradisional. Bandung: Alumni.

Undang-undang Nomor 28 Tahun 2014 tentang Hak Cipta

Undang-undang Nomor 5 Tahun 2017 tentang Pemajuan Kebudayaan, selanjutnya disingkat UUPK 2017.

Undang-undang Nomor 13 Tahun 2016 tentang Paten.

Undang-undang Nomor 20 Tahun 2016 tentang merek.

Undang-undang Nomor 7 Tahun 1994 tentang Persetujuan Pembentukan Organisasi Perdagangan Dunia.

Undang Undang No. 11 Tahun 2010 tentang Cagar Budaya 